\title{
STRATEGI PENGEMBANGAN USAHATANI KEDELAI DI KABUPATEN GROBOGAN DENGAN PENDEKATAN ANALYSIS HIERARCHY PROCESS (AHP)
}

\author{
Avi Budi Setiawan; Fafurida \\ Universitas Negeri Semarang \\ Email: avi_bs19@rocketmail.com
}

\begin{abstract}
Soybean is one of the agricultural commodity Grobogan. Soybean commodity is widely cultivated by farmers because the topography is consistent with the characteristics of the soil in Grobogan. In 2010 soybean production Grobogan is most widely in Central Java. However, Indonesia is still dependent on imported soybeans, especially in times of shortages of soybeans. This is partly also due to soybean production in soybean-producing region is very volatile while soybean demand in the market tends to increase. So, we need a strategy development of soybean farming in Grobogan. The goals to be achieved from the preparation of this study was to analyze the condition of soybean farming in Grobogan and obtain soybean farming development strategy in Grobogan based approach Analysis of Hierarchy Process. Alternative measures a priority to develop soybean are: Provision of continuous production factors and affordable, production factor subsidies, assistance to farmers, extension and education on effective post-harvest handling, Counseling institutional strengthening of farmer groups, and technical assistance (equipment, factors of production, training) to farmers. sedagkan least priority are: Incentives for active farmer organizations, cooperatives Revitalization and extension services and farmer partnerships with major employers
\end{abstract}

Keywords: Soybean, Analysis of Hierarchy Process

\section{PENDAHULUAN}

Pada era globalisasi dewasa ini dengan salah satu isu utamanya adalah ketahanan pangan maka sektor pertanian merupakan salah satu sektor utama yang memegang peranan penting dalam pembangunan ekonomi di Indonesia. Pertanian merupakan salah satu faktor penting mengingat kebutuhan konsumen akan pangan sangatlah besar, mata pencaharian sebagian besar penduduk Indonesia juga berasal dari sektor agraris. Pada abad modernisasi ini pengembangan sektor pertanian harus dilakukan mengingat komoditas pertanian tidak hanya menjadi barang konsumsi namun juga komoditas industri baik sebagai bahan baku, maupun barang siap konsumsi.

Sektor pertanian di Indonesia merupakan salah satu sektor utama penggerak perekonomian hal ini dibuktikan dengan kontribusi sektor pertanian terhadap PDB Indonesia merupakan yang terbesar kedua setelah sektor industri. Dalam pengembangannya sektor pertanian masih terkonsentrasi di pulau jawa terutama untuk komoditas tanaman pangan sehingga pulau jawa dapat dikatakan merupakan penopang sektor pertanian di Indonesia. 
Dimana dalam kontribusinya terhadap peta pertanian nasional provinsi Jawa Tengah merupakan salah satu wilayah agraris utama di pulau jawa.

Jawa Tengah merupakan salah satu sentra produksi utama komoditi tanaman pangan dan hortikultura di Indonesia (Sucihatiningsih: 2010). Beberapa komoditi palawija seperti jagung, kedelai, kacang hijau, dan kacang tanah merupakan potensi yang cukup besar sebagai pangan alternatif, sumber zat gizi dan pengembangan agroindustri, sedangkan beberapa komoditi hortikultura (bawang merah, bawang putih, cabe, kubis, kentang, mangga, durian, rambutan, salak, kelengkeng) merupakan komoditi agribisnis serta menjadi unggulan regional Provinsi ini.

Kabupaten Grobogan adalah Kabupaten dengan luas wilayah terluas ke 3 di Jawa Tengah terdiri dari 18 kecamatan. Dengan potensi luas wilayah yang besar menjadikan Kabupaten Grobogan sebagai salah satu lumbung pangan di Jawa Tengah bahkan Indonesia, mayoritas penduduk Kabupaten Grobogan juga bekerja di sektor pertanian. Sektor pertanian merupakan penyumbang terbesar dalam PDRB Kabupaten Grobogan dari tahun ke tahun. Dengan luas lahan pertanian yang besar serta ketersedian berbagai faktor produksi dan output sektor pertanian yang besar serta terdapat berbagai macam komoditas pertanian unggulan (padi, jagung, kedelai) maka pengembangan sektor pertanian di Kabupaten Grobogan perlu dilakukan guna peningkatan daya saing sektor pertanian dan peningkatan kesejahteraan petani

Kedelai merupakan salah satu komoditas andalan pertanian Kabupaten Grobogan. Komoditas kedelai ini banyak diusahakan oleh petani karena secara topografi memang sesuai dengan karakteristik tanah di Kabupaten Grobogan, oleh karena itu kedelai dapat tumbuh subur dan menguntungkan ketika dibudidayakan. Hingga tahun 2011 produksi kedelai Kabupaten Grobogan adalah salah satu paling banyak di Jawa Tengah, bahkan telah dipatenkan benih unggul kedelai yang dikembangkan di Kabupaten Grobogan dengan nama kedelai Varietas Grobogan. Selain itu, Kabupaten Grobogan merupakan salah satu sentra komoditas kedelai utama di Indonesia. Produksi kedelai dari Grobogan merupakan salah satu penopang utama terhadap total produksi kedelai nasional. 
Tabel 1

Produksi, Kedelai Provinsi Jawa Tengah Tahun 2011 (dirinci per Kabupaten)

\begin{tabular}{|c|c|c|c|}
\hline Kabupaten & $\begin{array}{c}\text { Luas Panen } \\
\text { (Ha) }\end{array}$ & $\begin{array}{l}\text { Produksi } \\
\text { (Ton) }\end{array}$ & $\begin{array}{c}\text { Produktivitas } \\
\text { (Ku/ Ha) }\end{array}$ \\
\hline Cilacap & 3.233 & 3.693 & 11,42 \\
\hline Banyumas & 4.051 & 7.14 & 17,63 \\
\hline Purbalingga & 204 & 306 & 15,00 \\
\hline Banjarnegara & 491 & 522 & 10,63 \\
\hline Kebumen & 8.403 & 11.562 & 13,76 \\
\hline Purworejo & 3.062 & 1.526 & 4,98 \\
\hline Wonosobo & 12 & 15 & 12,51 \\
\hline Magelang & - & - & - \\
\hline Boyolali & 2.478 & 4.082 & 16,47 \\
\hline Klaten & 4.228 & 6.266 & 14,82 \\
\hline Sukoharjo & 2.722 & 4.325 & 15,89 \\
\hline Wonogiri & 18718 & 22.359 & 11,95 \\
\hline Karanganyar & 617 & 846 & 13,71 \\
\hline Sragen & 3140 & 4.166 & 13,27 \\
\hline Grobogan & 7350 & 14.582 & 19,84 \\
\hline Blora & 3.548 & 4.004 & 11,29 \\
\hline Rembang & 4.256 & 3.732 & 8,77 \\
\hline Pati & 2.801 & 3.335 & 11,91 \\
\hline Kudus & 169 & 144 & 8,52 \\
\hline Jepara & 61 & 48 & 7,88 \\
\hline Demak & 2.99 & 7.24 & 24,21 \\
\hline Semarang & 326 & 411 & 12,61 \\
\hline Temanggung & 8 & 16 & 20,31 \\
\hline Kendal & 3.746 & 5.614 & 14,99 \\
\hline Batang & 77 & 88 & 11,41 \\
\hline Pekalongan & 59 & 60 & 10,15 \\
\hline Pemalang & 29 & 37 & 12,69 \\
\hline Tegal & 297 & 283 & 9,53 \\
\hline Brebes & 4.912 & 5.871 & 11,95 \\
\hline Kota Magelang & - & - & - \\
\hline Kota Surakarta & - & - & - \\
\hline Kota Salatiga & - & - & - \\
\hline Kota Semarang & - & - & - \\
\hline Kota Pekalongan & - & - & - \\
\hline Kota Tegal & - & - & - \\
\hline
\end{tabular}

Sumber: BPS Provinsi Jawa Tengah 2013

Akan tetapi selama ini Indonesia masih bergantung pada kedelai impor terutama pada saat terjadi kekurangan stok kedelai. Hal ini antara lain disebabkan juga karena produksi kedelai di wilayah penghasil kedelai sangat fluktuatif sedangkan permintaan kedelai di pasar cenderung mengalami peningkatan. kegiatan penanaman kedelai umumnya dilakukan pada musim kemarau, hal ini dikarenakan karakteristik kedelai bertipe tanaman kering. 
Tingginya kontribusi Kabupaten Grobogan terhadap total produksi komoditas pertanian di Jawa Tengah khususnya kedelai membuat Kabupaten Grobogan menjadi salah satu sentra kedelai di Provinsi Jawa Tengah terlebih dengan luas wilayah Kabupaten Grobogan adalah yang terbesar ketiga di Jawa Tengah tentu saja akan berdampak pada semakin besarnya lahan usahatani potensial yang digarap. Akan tetapi nilai PDRB Kabupaten Grobogan justru rendah bila dibandingkan dengan Kabupaten dan Kota lain. (Jawa Tengah Dalam Angka: 2012)

Pengembangan usahatani kedelai di Kabupaten Grobogan tidak dapat dilakukan secara parsial. Diperlukan kajian kebijakan dan perumusan strategi yang komprehensif mengingat kegiatan usahatani kedelai akan melibatkan sub sistem-sub sistem yang ada didalamnya. Kabupaten Grobogan merupakan salah satu penyangga utama akan komoditas-komoditas pertanian terutama tanaman pangan di Jawa Tengah dan Indonesia sehingga kajian akan strategi pengembangan komoditas kedelai di Kabupaten Grobogan merupakan sesuatu yang memiliki dimensi yang luas terutama terkait dengan aspek ekonomi serta potensi sumber daya.

Kebijakan pengembangan usahatani kedelai yang telah dilaksanakan baik oleh Pemerintah maupun pihak-pihak lain dianggap belum mampu meningkatkan kemampuan usahatani kedelai di Kabupaten Grobogan dalam menyangga perekonomian terutama di komoditas kedelai, serangkaian kebijakan yang telah diprogramkan dan dilaksanakan juga dirasa belum menyentuh hingga level petani di tingkat bawah. Oleh karena itu berdasarkan rumusan permasalahan diatas maka yang menjadi pertanyaan penelitian adalah sebagai berikut:

1. Bagaimana kondisi usahatani kedelai di Kabupaten Grobogan?

2. Bagaimana strategi pengembangan usahatani kedelai di Kabupaten Grobogan?

\section{Perumusan Strategi}

Perumusan strategi merupakan proses penyusunan langkah-langkah ke depan yang dimaksudkan untuk membangun visi dan misi organisasi, menetapkan tujuan strategis dan keuangan perusahaan, serta merancang strategi untuk mencapai tujuan tersebut dalam rangka menyediakan customer value terbaik. Beberapa langkah yang perlu dilakukan perusahaan dalam merumuskan strategi, yaitu:

Mengidentifikasi lingkungan yang akan dimasuki oleh perusahaan di masa depan dan menentukan misi perusahaan untuk mencapai visi yang dicita-citakan dalam lingkungan tersebut. Melakukan analisis lingkungan internal dan eksternal untuk mengukur kekuatan dan 
kelemahan serta peluang dan ancaman yang akan dihadapi oleh perusahaan dalam menjalankan misinya. Merumuskan faktor-faktor ukuran keberhasilan (key success factors) dari strategi-strategi yang dirancang berdasarkan analisis sebelumnya. Menentukan tujuan dan target terukur, mengevaluasi berbagai alternatif strategi dengan mempertimbangkan sumberdaya yang dimiliki dan kondisi eksternal yang dihadapi. Memilih strategi yang paling sesuai untuk mencapai tujuan jangka pendek dan jangka panjang. (Hariadi, 2005).

\section{METODE PENELITIAN}

Dalam penyusunan penelitian jenis data yang digunakan oleh peneliti adalah data primer dan data sekunder. Data primer diperoleh dari hasil wawancara langsung dengan para key person dalam usahatani kedelai dengan menggunakan daftar pertanyaan (kuesioner) dan pedoman wawancara.

Sedangkan data sekunder adalah data yang diperoleh dari catatan atau sumber lain yang telah ada sebelumnya dan diolah kemudian disajikan dalam bentuk teks, karya tulis, laporan penelitian, buku dan lain sebagainya. Data sekunder yang dibutuhkan diperoleh dari catatan BPS Jawa Tengah, Dinas Pertanian Tanaman Pangan dan Holtikultura Kabupaten Grobogan serta dari catatan-catatan laporan pertanian Kabupaten Grobogan.

Dalam penyusunan penelitian ini peneliti menggunakan analisis deskriptif kuantitatif dan deskriptif kualitatif, analisis deskriptif sendiri diartikan sebagai proses pemecahan masalah yang diselidiki dengan melukiskan keadaan subyek dan obyek penelitian pada saat sekarang berdasarkan fakta-fakta yang tampak atau bagaimana adanya. Denzin (1978) dalam Sucihatiningsih (2010) menggunakan istilah triangulasi untuk mengkonsepkan penggunaan metode gabungan dalam satu penelitian dimaksud. Metode gabungan dalam penelitian ini adalah pendekatan kuantitatif sebagai metode utama dan pendekatan kualitatif sebagai pengkayaannya. Setelah mendapat gambaran dari analisis deskriptif maka dilanjutkan dengan analisis strategi pengembangan usahatani kedelai melalui penggunaan Model Analitycal Hierarchy Proses (AHP) untuk menentukan strategi pengembangan komoditas kedelai di Kabupaten Grobogan. Seperti telah dijelaskan diatas metode AHP digunakan untuk memilih kriteria dan alternatif guna mencapai tujuan/ goal yaitu pengembangan usahatani kedelai di Kabupaten Grobogan. Adapun yang menjadi kriteria dan alternatif dari strategi pengembangan usahatani kedelai di Kabupaten Grobogan adalah sebagai berikut. 
Tabel 2

Kriteria dan alternatif dalam metode AHP

\begin{tabular}{|c|c|}
\hline Kriteria & Alternatif \\
\hline \multirow{3}{*}{$\begin{array}{l}\text { Aspek Faktor Produksi } \\
\text { (penyediaan Input) }\end{array}$} & - Subsidi faktor produksi \\
\hline & $\begin{array}{l}\text { - Investasi pihak swasta dalam penyediaan faktor } \\
\text { produksi }\end{array}$ \\
\hline & $\begin{array}{l}\text { - Penyediaan faktor produksi secara kontinyu dan } \\
\text { terjangkau }\end{array}$ \\
\hline \multirow[t]{3}{*}{ Aspek Budidaya } & - Pendampingan kepada petani \\
\hline & $\begin{array}{l}\text { - Merangsang pupuk organik dan pestisida } \\
\text { organik }\end{array}$ \\
\hline & $\begin{array}{l}\text { - Merangsang menggunakan benih unggul dan } \\
\text { berlabel. }\end{array}$ \\
\hline \multirow{3}{*}{$\begin{array}{l}\text { Aspek Kebijakan } \\
\text { Pemerintah }\end{array}$} & $\begin{array}{l}\text { - Dukungan kebijakan penetapan Harga Pokok } \\
\text { Penjualan (HPP) }\end{array}$ \\
\hline & - Kebijakan pembangunan infrastruktur \\
\hline & $\begin{array}{l}\text { Bantuan teknis (peralatan, faktor produksi, } \\
\text { pelatihan) kepada petani }\end{array}$ \\
\hline \multirow[t]{3}{*}{ Aspek Kelembagaan } & $\begin{array}{l}\text { - Penyuluhan penguatan kelembagaan kelompok } \\
\text { tani }\end{array}$ \\
\hline & - Insentif bagi lembaga tani yang aktif \\
\hline & - Revitalisasi KUD serta lembaga penyuluhan \\
\hline \multirow[t]{2}{*}{ Aspek Pasca Panen } & - Kemitraan petani dengan pengusaha besar \\
\hline & $\begin{array}{l}\text { - Penyuluhan dan edukasi tentang penanganan } \\
\text { pasca panen yang efektif. }\end{array}$ \\
\hline
\end{tabular}

Sumber: Data primer diolah

Pendekatan analisis deskriptif kualitatif digunakan untuk melengkapi dan mendukung kekayaan data pada analisis kuantitatif. Untuk mendapatkan informasi dalam analisis deskriptif kualitatif dilakukan melalui wawancara dan pengamatan mendalam. Wawancara dan pengamatan dilakukan kepada petani Analisis ini digunakan untuk mempertajam deskripsi tentang: (1) gambaran umum kondisi pertanian, (2) metode usahatani, (3) strategi kebijakan pengembangan komoditas pertanian. Seperti yang telah disebutkan diatas bahwa analisis deskriptif sendiri diartikan sebagai proses pemecahan masalah yang diselidiki dengan melukiskan keadaan subyek dan obyek penelitian pada saat sekarang berdasarkan fakta-fakta yang tampak atau bagaimana adanya. 


\section{HASIL DAN PEMBAHASAN}

\section{Gambaran Umum Petani di Kabupaten Grobogan}

Sektor pertanian merupakan sektor yang menjadi mata pencaharian utama bagi kebanyakan masyarakat di Kabupaten Grobogan. Umumnya petani-petani di Kabupaten Grobogan mengusahakan padi sebagai komoditas utama yang ditanam. Akan tetapi, intensitas penanamanya bergantung kepada kondisi lahan. Apabila lahan sawahnya adalah sawah irigasi maka padi dapat ditanam dua kali dalam satu tahun, tetapi apabila sawah merupakan tadah hujan maka padi hanya dapat ditanam selama satu kali dalam setahun. Petani di Kabupaten Grobogan merupakan masyarakat yang kebanyakan tinggal di daerah perdesaan mengingat sektor pertanian adalah sektor yang tumbuh dan menjadi penopang utama di wilayah perdesaan.

\section{Gambaran Umum Komoditas Kedelai di Kabupaten Grobogan}

Untuk jenis komoditas kedelai petani kedelai di Kabupaten Grobogan biasanya menggunakan jenis benih kedelai varietas grobogan. Varietas kedelai ini merupakan pengembangan dari kedelai varietas Malabar yang dikembangkan di Kabupaten Grobogan sehingga sekarang petani lebih banyak menanam kedelai ini. Petani kedelai lebih memilih jenis kedelai varietas grobogan karena secara teknis lebih tahan penyakit, waktu panen cepat dan kualitas biji yang dihasilkan sangat bagus. Selain juga karena merupakan varietas yang dibuat dan dikembangkan di daerah sendiri.

Kedelai varietas grobogan sangat mudah didapat, sehingga apabila petani ingin menanam kedelai maka tinggal mencari di toko pertanian. Kedelai ini dikembangkan oleh pemerintah berkerja sama dengan pihak swasta dan melibatkan petani.

\section{Prioritas Kebijakan Alihfungsi Lahan}

Dalam penyusunan strategi pengembangan komoditas tanaman pangan kedelai di Kabupaten Grobogan terdapat dari 5 kriteria dan 14 alternatif atau sama dengan komoditas padi dan jagung. Untuk keempat belas alternatif ini dapat diketahui secara berurutan mulai dari alternatif yang paling prioritas hingga yang paling tidak prioritas. Pada bagian ini akan dijelaskan mengenai alternatif-alternatif yang paling prioritas secara keseluruhan. Jadi akan disajikan urutan 14 alternatif dari yang paling prioritas hingga yang paling tidak prioritas berdasarkan analisis AHP. Berikut disajikan gambar tentang alternatif strategi pengembangan komoditas tanaman pangan kedelai di Kabupaten Grobogan sebagai berikut: 
Berdasarkan hasil olah data diatas maka dapat diketahui bahwa dari keempatbelas alternatif yang ada tenyata alternatif penyediaan faktor produksi secara kontinyu dan terjangkau merupakan alternatif yang terpenting guna mengembangkan komoditas tanaman pangan kedelai dengan persentasi prioritas sebesar $25,1 \%$. Selanjutnya alternatif yang paling penting kedua adalah subsidi faktor produksi dengan persentase 16,3\%. Alternatif yang menjadi prioritas ketiga dengan persentase prioritas sebesar $12,5 \%$ adalah pendampingan kepada petani.

Sedangkan alternatif yang paling tidak proritas dalam pengembangan komoditas tanaman pangan kedelai adalah kemitraan petani dan pengusaha besar di peringkat 12 dengan persentase prioritas $2,1 \%$. Prioritas ketiga belas adalah revitalisasi KUD serta lembaga penyuluhan dengan persentase 2,0\%.dan alternatif yang menjadi prioritas terakhir adalah insentif bagi lembaga tani yang aktif dengan persentase $0,9 \%$.

\section{Gambar 4.8}

\section{Urutan Alternatif Strategi Pengembangan Komoditas Kedelai} dari yang Paling Prioritas

\begin{tabular}{|c|l|c|}
\hline Prioritas & \multicolumn{1}{|c|}{ Alternatif } & Persentase \\
\hline 1 & Penyediaan faktor produksi secara kontinyu dan terjangkau & $25,1 \%$ \\
\hline 2 & Subsidi faktor produksi & $16,3 \%$ \\
\hline 3 & Pendampingan kepada petani & $12,5 \%$ \\
\hline 4 & Penyuluhan dan edukasi tentang penanganan pasca panen yang efektif & $9,6 \%$ \\
\hline 5 & Penyuluhan penguatan kelembagaan kelompok tani & $6,8 \%$ \\
\hline 6 & Bantuan teknis (peralatan, faktor produksi, pelatihan) kepada petani & $6,6 \%$ \\
\hline 7 & Kebijakan pembangunan infrastruktur & $5,0 \%$ \\
\hline 8 & Dukungan kebijakan penetapan Harga Pokok Penjualan (HPP) & $3,8 \%$ \\
\hline 9 & Investasi pihak swasta dalam penyediaan faktor produksi & $3,2 \%$ \\
\hline 10 & Merangsang menggunakan benih unggul dan berlabel & $3,0 \%$ \\
\hline 11 & Merangsang pupuk organik dan pestisida organik & $2,9 \%$ \\
\hline 12 & Kemitraan petani dengan pengusaha besar & $2,1 \%$ \\
\hline 13 & Revitalisasi KUD serta lembaga penyuluhan & $2,0 \%$ \\
\hline 14 & Insentif bagi lembaga tani yang aktif & $0,9 \%$ \\
\hline & Total & $\mathbf{1 0 0 \%}$ \\
\hline
\end{tabular}

Sumber: Data primer diolah

\section{PEMBAHASAN}

Analisis AHP digunakan untuk merumuskan strategi prioritas dalam mengembangkan komoditas kedelai di Kabupaten Grobogan. Perumusan alternatif dan prioritas ini dibuat sekomprehensif mungkin untuk menyentuh semua kemungkinan yang dimungkinkan berperan dalam pengembangan komoditas kedelai. Apabila diurutkan dan dijadikan satu 
kedalam satu tabel yang komprehensif. Maka kriteria dan alternatif yang menjadi prioritas untuk masing-masing komoditas adalah sebagai berikut.

Apabila dilihat lebih lanjut maka terdapat beberapa aspek yang menjadi kriteria utama. Aspek-aspek yang paling menjadi prioritas antara lain aspek faktor produksi. Pengembangan komoditas kedelai dianggap memerlukan sebuah strategi pengembangan yang terkait aspek faktor produksi. Petani di Kabupaten Grobogan membutuhkan sesuatu yang sifatnya teknis dan aplikatif. Aspek faktor produksi sangat terkait dengan penyediaan input yang seperti diketahui bersama penggunaan input ini sangatlah penting bagi petani karena apabila tanpa faktor produksi yang tersedia secara kontinyu maka usahatani tidak akan maksimal.

Aspek budidaya juga merupakan aspek yang penting bagi pengembangan komoditas kedelai. Petani di Kabupaten Grobogan sebagaimana telah diketahui bersama memiliki update pengetahuan yang rendah mengenai usahatani yang digeluti. Sebagai contoh, petani sering ketinggalan informasi tentang jenis varietas bibit unggul yang dikembangkan oleh lembaga riset. Memang sekarang ini di era globalisasi, banyak perusahaan benih yang telah bekerja sama dengan petani untuk menanam benih yang diproduksi dari pabrik-pabrik mereka. Hal ini merupakan sebuah fakta dan fenomena empiris yang sebenarnya menguntungkan jika dilihat secara parsial. Namun, apabila dikaji lagi secara mendalam hal ini lebih bersifat destruktif bagi petani. Petani memang diberikan produk hasil inovasi baru, akan tetapi itu merupakan strategi dari perusahaan untuk membangun kemitraan kepada petani tetapi hanya menguntungkan satu pihak saja. Setelah perusahaan menguasai pasar pemasaran benih maka mereka akan menaikan harga benih karena perusahaan mengejar keuntungan yang besar. Benih hasil pengembangan dari lembaga riset, universitas yang concern pada pengembangan pertanian tidak berkembang karena kurang mendapat dukungan untuk dibudidayakan oleh para petani lokal.

Perlu pendampingan kepada petani oleh penyuluh pertanian untuk menjamin petani diayomi oleh pemerintah. Peran penyuluh secara psikologis oleh petani dianggap mampu memberikan rasa tentram kepada mereka karena petani merasakan telah mendapat dukungan dari wakil pemerintah yang dalam hal ini penyuluh pertanian. Petani akan mendapatkan informasi baru tentang usahatani, peralatan pertanian yang modern, faktor produksi yang efisien serta informasi pasar dan juga treatment tentang penanggulangan hama penyakit. Memang benar apabila banyak petani masih berpikiran sederhana dan sulit untuk menerima hal baru bahkan hanya update informasi dan pengetahuan saja sering tidak pernah dilakukan oleh petani. Sedang disisi lain, petani kadangkala membutuhkan bantuan penyuluh pertanian 
apabila tanaman mereka terserang hama penyakit. Perlu sebuah pendekatan yang arif dalam menyikapi kondisi ini. Penyuluh pertanian perlu mengerti kondisi petani yang dibinanya, memahami kearifan lokal serta menyampaikan pengetahuan kepada petani dengan model pembelajaran yang dibangun berdasarkan basis komunikasi dan kesetaraan. Petani pun juga harus mampu membuka diri dengan pengetahuan baru, jangan sekedar mentoleransi ketidaktahuan mereka dengan ketidak pedulian. Harus ada upaya merubah mindset petani dalam memandang usahatani sebagai mata pencaharian.

Sedangkan aspek prioritas yang selanjutnya dalam pengembangan komoditas kedelai adalah aspek pasca panen. Aspek ini dianggap cukup urgent dalam peta upaya pengembangan komoditas tanaman kedelai. Pasca panen sebenarnya merupakan sebuah aspek yang penting. Sebagai contoh, ketika pada saat panen raya kedelai tiba banyak petani menjual panen mereka dengan sistem ijon kepada tengkulak. Hal ini akan mengakibatkan keuntungan potensial yang diperoleh petani menurun karena harga jual kedelai basah jauh di bawah harga beras. Kondisi ini disebabkan karena penanganan pasca panen untuk komoditas pertanian terutama kedelai masih kurang optimal, bisa disebabkan karena keterbatasan teknologi dan pengetahuan namun juga bisa karena dorongan untuk mrndapatkan uang cepat. Bulog juga tidak menjalankan tugas lagi untuk menyerap kedelai dari petani.

Kemudian aspek kebijakan pemerintah walaupun menjadi prioritas terakhir namun juga memerlukan kajian yang lebih cermat. Petani dirasakan sangat membutuhkan dukungan kebijakan perlindungan berupa penetapan harga pokok penjualan atau harga jual terendah untuk komoditas mereka. Jadi petani dianggap lebih membutuhkan dukungan berupa perlindungan harga jual produk pertanian karena aspek harga jual ini selalu dikaitkan dengan posisi tawar petani yang rendah.

Aspek budidaya juga menjadi aspek prioritas terlebih dalam teknis usahatani kedelai. Petani perlu mendapatkan pendampingan dan dukungan dalam menjalankan kegiatan usahtani kedelai, hal itu juga didorong dengan upaya menggunakan benih kedelai varietas grobogan yang dikembangkan di Kabupaten Grobogan. Pengembangan benih kedelai unggulan dan produk lokal ini perlu ditingkatkan. Selain itu, untuk mengurangi ketergantungan akan faktor-faktor produksi konvensional yang tinggi perlu dimulai usaha untuk mulai menggunakan pupuk organik dari kotoran binatang dan pestisida organik.

Aspek infrastruktur juga menjadi elemen penting bagi pengembangan komoditas kedelai di Kabupaten Grobogan. Selama ini, perhatian pemerintah dan pihak-pihak terkait 
yang bertanggung jawab masih terfokus pada komoditas padi dan jagung yang lebih banyak ditanam petani. Padahal, komoditas kedelai merupakan komoditas yang sangat penting karena Kabupaten Grobogan merupakan penyedia kedelai terbesar di Jawa Tengah bahkan Indonesia oleh karena itu infrastruktur kedelai harus diperhatikan.

Infrastruktur yang dimaksud penting dalam pengembangan komoditas kedelai antara lain jaringan pengairan untuk lahan tanam kedelai. Tanaman kedelai memang tidak memerlukan banyak air akan tetapi ketersediaan air melalui pembangunan embung-embung di sawah, sumur-sumur di tengah sawah harus ditambah untuk memastikan ketersediaan air bagi tanaman kedelai terjamin. Selain itu, perlu dibangun pusat pasar kedelai di sentra-sentra kedelai agar menjadikan kedelai bukan lagi komoditas yang diperebutkan tengkulak dan spekulan namun sebagai tempat untuk mempertemukan pembeli besar dan pembeli akhir dengan petani kedelai atau gabungan petani kedelai sebagai penjual kolektif di pasar. Pasar pemasaran pada sentra-sentra kedelai ini juga dapat digunakan sebagai sarana untuk menetapkan harga standar jual kedelai pada level petani sehingga menghindari terjadinya praktek spekulasi harga. Hal ini dilakukan mengingat berdasarkan pengalaman petani komoditas kedelai ini sangat rawan spekulasi. Harga jual kedelai dapat dengan mudah berubah drastis dalam waktu yang sangat singkat. Kondisi ini tentu saja sangat merugikan petani kedelai karena mereka tidak dapat mempengaruhi harga.

Subsidi faktor produksi seperti pupuk, benih unggul dan obat-obatan juga perlu ditingkatkan untuk mengembangkan komoditas kedelai di Kabupaten Grobogan. Subsidi yang ada selama ini masing kurang dalam memenuhi kebutuhan petani akan faktor produksi yang penting seperti pupuk dan benih unggul. Pupuk bersubsidi merupakan salah satu faktor produksi yang penyediaanya diharapkan dapat ditambah seiring dengan upaya peningkatan produksi. Namun, penambahannya juga harus diimbangi dengan upaya pendampingan kepada petani agar dapat menggunakan dengan efisien dan tidak berlebihan. Petani memang memerlukan mekanisme perlindungan dari pemerintah. Sedangkan salah satu mekanisme perlindungan kepada petani adalah dengan diberikan subsidi kepada mereka. Dengan subsidi setidaknya akan mengurangi biaya produksi petani dan membuat mereka meningkat daya saingnya karena harga yang bersaing dan kualitas panen yang baik sebab faktor produksinya diberikan secara optimal.

Penyuluh pertanian juga perlu untuk memberikan dorongan kepada petani supaya menggunakan benil lokal yaitu benih kedelai varietas grobogan untuk dibudidayakan. 
Kedelai varietas grobogan merupakan varietas benih kedelai yang telah disertifikasi dan termasuk jenis benih kedelai unggul sehingga perlu untuk terus dibudidayakan. Selain sebagai perwujudan rasa bangga kepada produk benih lokal. Terlebih penggunaan benih kedelai lokal lebih meminimumkan biaya produksi karena umumnya dijual dengan harga yang lebih murah bahkan bisa dikembangkan sendiri oleh petani dengan cara menyisihkan kedelai hasil panen untuk dipersiapkan sebagai benih dengan maksud ditanam pada periode masa tanam berikutnya.

Bantuan teknis kepada petani kedelai merupakan salah satu instrumen teknis yang perlu dilaksanakan. Petani kedelai memerlukan banyak sekali bantuan dari pemerintah maupun pihak terkait. Misalnya bantuan pompa air, alat pengering benih kedelai, dan lain sebagainya. Bantuan ini harus diberikan dengan terlebih dahulu melakukan pemetaan mengenai kelompok tani mana saja yang membutuhkan bantuan peralatan tertentu. Hal ini dilakukan mengingat azas kebermanfaatan dan kesesuaian bantuan yang dibutuhkan dengan realisasi bantuan. Sebab, sering ditemui kejadian di lapangan bahwa banyak kelompok tani yang mendapatkan bantuan peralatan pertanian seperti mesin pengering benih kedelai dan peralatan lain namun setelah bantuan peralatan tersebut sampai kepada petani alat tersebut tidak digunakan lagi oleh petani karena ketidakmampuan dalam pengorerasian dan ketidak sesuaian antara kebutuhan dan bantuan yang datang.

\section{KESIMPULAN DAN SARAN}

Dari penelitian yang telah dilakukan ini diperoleh beberapa kesimpulan antara lain bahwa kondisi petani komoditas kedelai di Kabupaten Grobogan kebanyakan didominasi oleh petani dengan struktur umur yang telah tua, berlatar belakang pendidikan rendah dan masih menjalankan kegiatan pertanian secara tradisional secara turun-temurun. Strategi pengembangan kedelai berdasarkan urutan prioritas kriteria pengembangan adalah sebagai berikut: aspek yang menjadi prioritas utama adalah aspek faktor produksi, aspek budidaya, aspek pasca panen, aspek kelembagaan dan aspek kebijakan pemerintah.

Adapun rekomendasi berdasarkan hasil penelitian ini adalah perlunya Pemerintah Kabupaten Grobogan disarankan untuk mengaplikasikan strategi pengembangan komoditas tanaman pangan kedelai berdasarkan prioritas kriteria dan alternatif yang telah dirumuskan berdasarkan hasil penelitian. Berdasarkan hasil yang diperoleh, pemerintah Kabupaten Grobogan disarankan untuk lebih memfokuskan pengembangan komoditas unggulan tanaman pangan kedelai di sentra daerah pengembangan. Pemerintah daerah juga disarankan untuk 
mendorong upaya intensifikasi dan peningkatan produktivitas lahan melalui programprogram peningkatan kemampuan petani, peningkatan dan perbaikan sarana dan prasarana penunjang produksi tanaman pangan. Perlu ada sebuah kebijakan mempengaruhi harga yang aplikatif menyentuh kepada petani untuk meningkatkan kesejahteraan mereka. Penetapan kebijakan harga pokok penjualan (HPP) untuk komoditas padi perlu dilakukan dengan berkerjasama dengan petani melalui kelompok tani, sehingga kelompok tani dapat memenuhi standar kualitas produk yang diminta oleh BULOG. Sebab selama ini permasalahan yang timbul adalah petani tidak mampu mengolah hasil panen mereka karena ketiadaan sarana pengolah padahal standar gabah untuk masuk ke BULOG mensyaratkan standar terkait kualitas produk yang dikirim. Perlu juga kebijakan selling price dan floor price untuk komoditas jagung dan kedelai untuk meningkatkan posisi tawar petani.

\section{DAFTAR PUSTAKA}

Arikunto, Suharsimi.2002. Prosedur Penelitian : Suatu Pendekatan Praktek. Jakarta : Rineka Cipta.

Arsyad, Lincolin. 2004. Ekonomi Pembangunan. Yogyakarta : STIE YKPN

Baehaqi, Achmad. 2007. Pengembangan Komoditas Unggulan Tanaman Pangan di Kabupaten Lampung Tengah. Tesis, Institut Pertanian Bogor

Budi Setiawan, Avi. 2008. Analisis Efisiensi Penggunaan Faktor-faktor Produksi Usahatani Jagung Di Kabupaten Grobogan tahun 2008, Skripsi, UNNES

Badan Bimas Ketahanan Pangan. 2001. Rencana Strategis dan Program Kerja Pemantapan Ketahanan Pangan 2001-2004. Badan Bimas Ketahanan Pangan. Jakarta.

BPS Provinsi Jawa Tengah. 2007. Jawa Tengah Dalam Angka: Jawa Tengah.

BPS Provinsi Jawa Tengah. 2009. Jawa Tengah Dalam Angka: Jawa Tengah.

BPS Kabupaten Grobogan 2007. Grobogan Dalam Angka: Grobogan

BPS Kabupaten Grobogan 2008. Grobogan Dalam Angka: Grobogan

Dinas Pertanian dan Perkebunan Kabupaten Grobogan, 2007, Luas Panen dan Produksi Tanaman Jagung Tahun 2002-2007: Grobogan.

Dinas Pertanian dan Perkebunan Kabupaten Grobogan. 2006, Petunjuk Pelaksanaan Program intensifikasi Tanaman pangan dan perkebunan. Grobogan.

Mason, R.D.,1996, Teknik Statistika untuk Bisnis dan Ekonomi, Jakarta: Erlangga

Mosher, A.T., 1978, An Introduction to Agricultural Extension, Agricultural Development Council, New York 
Mosher, A.T, 1985. Menggerakkan dan Membangun Pertanian Saduran Krisnandhi C.V. Yasaguna, Jakarta.

Mubyarto, 1989, Pengantar Ekonomi Pertanian, Jakarta : LPES.

Nicholson, Walter. 2002, Mikro Ekonomi Intermediate. Jakarta. Erlangga

Permadi, Bambang. 1992. Analysis Hierarchy Process. Jakarta. PAU EK Universitas Indonesia

Saaly, TL. 1987. The Analytic Hierarchy Process- What it is and How it is used, Math Modelling, Pergamon Journals Ltd. Great Britain

Situs Resmi Pemerintah Kabupaten Grobogan. http://www.grobogankab.go.id.

Situs Resmi Pemerintah Provinsi Jawa Tengah. http://www.jawatengah.go.id.

Soekartawi, 2003. Teori Ekonomi Produksi Dengan Pokok Bahasan Analisis Fungsi CobbDouglas (Theory of Production Economics with Special Discussion on Cobb-Douglas Production Function). 3rd Edition, Raja Grafindo Persada, Jakarta.

Sukirno,Sadono, 2005, Mikro Ekonomi Teori Pengantar, Raja Grafindo Persada: Jakarta

Sucihatiningsih, DWP, 2010. Model Penguatan Kapasitas Kelembagaan Penyuluh Pertanian dalam Meningkatkan Kinerja Usaha Tani: Studi Empiris di Provinsi Jawa Tengah . Disertasi. UNDIP

Suryana, Sawa, 2007. Analisis Faktor-faktor yang Mempengaruhi Produksi Jagung di Kabupaten Blora (Studi Kasus Produksi Jagung Hibrida di Kecamatan Banjarejo Kabupaten Blora). Tesis. UNDIP

Susilowati, Indah, Mudjahirin T, Waridin, Tri Winarni A, Agung S. 2004. Pengembangan Model Pemberdayaan Usaha Mikro Kecil, Menengah dan Koperasi Dalam Mendukung Ketahanan Pangan di Kabupaten dan Kota Pekalongan. RUKK Kantor Menneg Ristek dan LIPI. Jakarta.

Susilowati, Indah. 2009. Penguatan Kinerja Agribisnis Tanaman Pangan Unggulan Provinsi Jawa Tengah dalam Mendukung Ketahanan Pangan. Penelitian Sosial Ekonomi Pertanian. Kerjasama UNDIP dan Badan Litbang. Deptan.

Syahyuti. 1995. Pendekatan Kelompok dalam Pelaksanaan Program/Proyek Pembangunan Pertanian. Majalah Forum Agro Ekonomi. Vol. 13. No. 2 Desember 1995.

Syahyuti. 2002. Pembentukan Struktur Agraria pada Masyarakat Pinggiran Hutan. Tesis pada Jurusan Sosiologi Pedesaan. IPB, Bogor 
Syahyuti. 2003. Pembangunan pertanian indonesia dalam pengaruh kapitalisme dunia: analisis ekonomi politik perberasan. Pusat penelitian dan pembangunan sosial ekonomi pertanian.

Vu. Linh H. 2004. Efficiency of Rice Farming Households in Vietnam :A DEA with Bootstrap and Stochastic Frontier Application. University of Minnesota. USA

Yotopoulos, Pan A and JB Nugget. 1976, Economic of Development: Empirical Investigation, Harper International. USA

Yulianik, Siswi. 2006. Analisis Efisiensi penggunaan Faktor-faktor Produksi pada Usahatani Bawang Merah di Kabupaten Brebes (Studi Kasus di Desa larangan). Skripsi. UNDIP 